\title{
EFFECT OF SEDATIVE TECHNIQUES ON PHYSIOLOGICAL PARAMETERS OF CALVES AT (MINOR SURGICAL PROCEDURES) L OR HERNIORRAPHY
}

\author{
N.C.Sarker ${ }^{1}$, M.A.Hashim ${ }^{1}$, and B.P.Ray ${ }^{1}$
}

\begin{abstract}
The effect of sedatives and analgesics on heart rate, respiration rate and rectal temperature were observed. Heart rate and respiration rate significantly $(p<0.01)$ decreased during sedation with xylazine hydrochloride plus $2 \%$ lignocaine hydrochloride or $0.5 \%$ bupivacaine hydrochloride. A significantly decreased $(p<0.01)$ heart rate and respiration rate also found during sedation with diazepam plus $2 \%$ lignocaine hydrochloride or $0.5 \%$ bupivacaine hydrochloride. Two percent lignocaine hydrochloride showed short onset, rapid spreading and no side effect. Duration of analgesia was longer with $0.5 \%$ bupivacaine hydrochloride (55.88 $\pm 1.58 \mathrm{~min}$ in Group B and $48 \pm 11.25 \mathrm{~min}$ in Group D) compared to $2 \%$ lignocaine

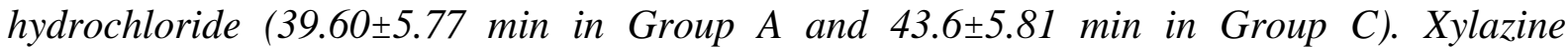
hydrochloride showed short onset and long duration of sedation compared to diazepam. Therefore, herniorraphy, xylazine hydrochloride can be used as a better sedative while $0.5 \%$ bupivacaine hydrochloride can be used as a local analgesic for longer duration of action.
\end{abstract}

Key words: Lignocaine hydrochloride, sedation, analgesia

\section{INTRODUCTION}

Diseases in calves are thought to be important constraints for cattle development in Bangladesh. It has been reported that $15-20 \%$ calves die per year from various diseases (Anon, 1993). Congenital disorders in calves have been increasing alarmingly. Umbilical hernia and atresia ani are among the major congenital disorders causing mortality in calves. Umbilical hernia is one of the major congenital affections in animal particularly in the bovine. The affected calves may only be treated through successful herniorraphy.

Clinical experience suggests that along with indigenous calves a considerable number of cross-bred calves also suffer from various congenital abnormalities. The surgical affections of calves may affect total performance of the dairy herds and above all the future generation and their health. New born calves frequently suffer from various surgical affections such as umbilical hernia, atresia ani, dermoid cyst, knuckling of the limbs, navel ill, umbilical abscesses. Das BR and Hashim,MA(1996) reported a high incidence (47.1\%) umbilical hernia among surgical affection in calves. This congenital defect may become dangerous if not treated in appropriate time. The affected calves may be only treated through successful herniorraphy. Many factors e.g. suture materials, suture pattern, degree of protrusion; body circumference, ring diameter etc determine the success of herniorraphy (Peacock and Van Winkle, 1976). Sedatives are used for premedication which is an essential part of balanced anaesthetic regimen. This is necessary for both general and local anaesthesia (Hall and Clarke, 1989). Local 
analgesia is considered to be very important in ruminant anaesthesia because general anaesthesia in ruminants very often lead to tympanities or regurgitation especially if anaesthesia is performed in unstarved condition (Hossain SS and Kumar A, 1988; Hashim MA, 2004). Therefore herniorraphy in calves are performed under sedation and local analgesia or regional analgesia.

Efficiency in operative procedure in a part depends on efficient anaesthesia. A sedative may be used to keep the animal quiet. The sedatives have been used in calves either alone or in combination with local, regional or general anaesthesia. The use of sedatives in veterinary practice is indispensable as they help in overcoming résistance of the animal during examination, maintaining depth of anaesthesia, reducing the dose of anaesthetic agent and increasing the margin of safety. Sedation of calves along with local anaesthetic is performed for the treatment of surgical interferences such as herniorraphy. Thus, action of some sedatives and local analgesics in various regional anaesthesia in calves and their evaluation in respect of doses are of great significance. The approximation of dose rate of available sedatives in calves may be helpful for the practitioners.

The commonly used local analgesic agents include lignocaine hydrochloride, lignocaine hydrochloride with adrenaline and bupivacaine hydrochloride. These local analgesic agents are used for local or regional analgesia. Lignocaine has a relatively rapid onset of action and intermediate duration of about 1 to 2 hours (Lumb and Jones, 1996; Carpenter et al., 2004). Bupivacaine is a long acting local analgesic. It is about 4 times more potent than lignocaine and is used most commonly for regional nerve block (Eugene and Nicholas, 1995). The experiment was carried out to determine the general effect of clinically useful dose of the sedatives in calves and study the action of various sedatives and local analgesics in calves and to investigate the effect of sedatives and various analgesics on the clinical parameters in calves.

\section{MATERIALS AND METHODS}

\section{Experimental Animal}

The study was carried out in the operation theatre of veterinary clinic, Bangladesh Agricultural University, Mymensingh, Gaibandha, Shirajgang and Kurigram District. The experiment was performed on 20 calves of ages ranging from 5 days to 4 months and body weights varied from 20 to $48 \mathrm{~kg}$. Out of 20 calves affected with umbilical hernia, 6 were indigenous (local) and 14 were crossbred. They were divided into 4 groups and each group included 5 calves. The calves were apparently healthy.

\section{Preparation of Animals}

The animals were starved of both food and water for 3 hours before sedation. An assistant restrained the animal physically and the drug was injected intramuscularly.

\section{Observation in animals}

Immediately after injection of drugs the animals were observed for various behavioral changes i.e. changes in attitude, outlook, and posture and time parameters like onset time, down time and recovery time.The depth of sedation and local analgesia were assessed by monitoring various ocular reflexes, pain prick reflexes, relaxation of neck, jaws, salivation, lacrimation, urination and granting. Respiration rate, heart rate an rectal temperature were observed.

\section{Use of Sedatives}

Diazepam (Seduxen $\left.{ }^{\circledR}\right)$ :

Diazepam (Seduxen®, Jayson Pharmaceuticals Ltd, and Bangladesh) is probably the most widely used 
N.C.Sarker, M.A.Hashim and B.P.Ray

benzodiazepines available in Bangladesh in $10 \mathrm{mg} / 2 \mathrm{ml}$ ampoule and commonly used in human medicine.

Xylazine hydrochloride (Rompun®)

Xylazine hydrochloride (Rompun®, 25ml vial each $\mathrm{ml}$ contain $23.32 \mathrm{mg}$ xylazine hydrochloride, Bayer, Leverkusen, Germany) is commonly used Alpha-2 adrenoceptor agonist in Bangladesh.

\section{Use of Analgesics}

2\% Lignocaine hydrochloride (Jasocaine ${ }^{\circledR}$ ) Lidocaine hydrochloride (Jasocaine ${ }^{\circledR}, \quad$ Jason Pharmaceuticals Ltd,Bangladesh) is one of most versatile and one of the most widely used local analgesic in veterinary medicine.

$0.5 \%$ Bupivacaine hydrochloride (Ultracaines $\left.{ }^{\circledR}\right)$ Bupivacaine hydrochloride (Ultracaine ${ }^{\circledR}$, Jason Pharmaceuticals Ltd, and Bangladesh) is an amide type local analgesic. Bupivacaine is a long acting local analgesic.

\section{Experimental Design}

The experimental animals were divided into four (4) different groups and allocated the following local anaesthetic agents, sedative and local infiltration in the following:

Group A. Xylazine hydrochloride Lignocaine hydrochloride combination in inverted ' $\mathrm{V}$ ' from anterior local infiltration analgesia.

Firstly xylazine hydrochloride (Rompun ${ }^{\circledR}$ ) was injected at a dose rate of $0.1 \mathrm{mg} / \mathrm{kg}$ body weight intramuscularly. Ten minute later 2\% lignocaine hydrochloride (Jasocaine ${ }^{\circledR}$ ) was injected at a dose rate of $10 \mathrm{ml}$ and then required dose for local infiltration.

Group B. Xylazine hydrochloride Bupivacaine hydrochloride combination in inverted "U" from anterior local infiltration analgesia The animals of this group were sedated using xylazine hydrochloride (Rompun®) @ ${ }^{\circledR}$ ) $11 \mathrm{mg} / \mathrm{kg}$ intramuscularly and were local analgesized using $0.5 \%$ bupivcaine hydrochloride (Ultracaines $\AA$ ) ten minute later for local infiltration.

Group C. Diazepam - Lignocane hydrochloride combination in ring shaped local infiltration analgesia

At first diazepam (Seduxen ${ }^{\circledR}$ ) was injected at a dose rate of $0.5 \mathrm{mg} / \mathrm{kg}$ body weight intramuscularly. Twenty to thirty minute later 2\% lignocaine hydrochloride (Jasocaine ${ }^{\circledR}$ ) was injected at a dose rate of $10 \mathrm{ml}$ and then required dose for local infiltration.

Group D. Diazepam - Bupivacaine hydrochloride combination in inverted $\mathrm{L}$ shaped local infiltration analgesia.

Twenty to thirty minute prior to analgesia diazepam (Seduxen ${ }^{\circledR}$ ) was injected at a dose rate of $0.5 \mathrm{mg} / \mathrm{kg}$ body weight intramuscularly, $\quad 0.5 \%$ bupivacaine hydrochloride (Ultracaine $\AA$ ) was injected at a dose rate of $10 \mathrm{ml}$ and then required dose for local infiltration.

\section{Clinical Parameters}

Respiratory rate, heart rate and rectal temperature were recorded before administration of sedatives and at 15, 30, 45, 60 minutes after sedation and local analgesia.

\section{Heart rate}

Heart rate was recorded using a ethoscope. For this the diaphragm of the stethoscope was placed over the left side of the chest and the heart beat was counted for one minute.

\section{Respiratory rate}

Respiratory rate was recoded by keeping the chest piece of the stethoscope over the thorax (auscultation). 


\section{Rectal temperature}

The rectal temperature was taken by inserting a clinical thermometer at least $1.5-2.0 \mathrm{~cm}$ into the rectum. Correction of Hernia (Herniorraphy)

\section{Requirements}

Surgical handle \& blade, forceps, artery forceps, blade, cotton, swab, catgut, nylon thread, syringe, draping cloth, towel clip, tissue forceps, surgical needle, needle holders, anaesthetic agent and antiseptic.

\section{Procedure}

Surgical access is usually obtained by incision either directly over or around the hernial sac; the calf was controlled on the dorsal recumbence by casting and by the help of an assistant. Clipping, shaving, antiseptic, sedation and analgesia of the region was performed. Required amount of analgesic was used. A line block was made by inserting the needle anterior to the hernial ring to make an inverted "V". Tincture of iodine was painted over the sac and surrounding tissue Operations in most calves were performed here by giving incision in para midline method where access to the hernial contents and the ring were found suitable. Herniated tissues may have reduced viability and increased friability requiring careful handling. Incarcerated and irreducible hernias were rare in case of calves so the handling was not so difficult.

Hernial ring was not to be enlarged to facilitate return of the hernial contents.

The basic principle of hernia repair is to close normal tissue to normal tissue without undue tension (Slatter, '1985). The loops of the hernia sac are being required to remove a considerable part to make the lower abdominal wall in a proper condition. In most calves, loop of the hernial sac were removed Closure of the hernial neck (ring) was made by mattress sutures by using catgut. A small amount of sulphonilamide powder was used before closing the skin.

The loose part of the skin at the umbilical region was also removed to make the abdominal skin approximated. A series of mattress stitches were used by utilizing nylon thread.

\section{Statistical Analysis}

Student's paired " $t$ " test was performed to compare the obtained before anaesthesia and $15 \mathrm{~min}$. $30 \mathrm{~min}$. $45 \mathrm{~min}$. and $60 \mathrm{~min}$. after anaesthesia. Analysis of variance (ANOVA test) in completely randomized design was carried out to test significance of variation among the effects in different time interval. The mean of data with its standard deviation (SD) and standard error mean (SEM) were calculated. The results were analyzed by the least significant difference test in "MSTAT" computer programmer.

\section{RESULTS AND DISSCSION}

\section{General Signs after Administration of} Sedatives in Calf Xylazine hydrochloride Drooping of the upper eyelids, droopy head, salivation and lateral recumbency were observed in all the calves after onset of sedation with xylazine hydrochloride at the dose rate of $0.13 \pm 00 \mathrm{mg} / \mathrm{kg}$ and $0.12 \pm 0.01 \mathrm{mg} / \mathrm{kg}$ in Group A and Group B respectively.

There was milk fever like recumbency and muscle relaxation was observed. The calf of Group A and Group B showed severe drowsiness $8 \pm 0.71 \mathrm{~min}$ and $7 \pm 0.71 \mathrm{~min}$ after administration of xylazine hydrochloride respectively.

\section{Diazepam}

Diazepam at the dose rate of $1.02 \pm 0.05$ $\mathrm{mg} / \mathrm{kg}$ and $1.06 \pm 0.04 \mathrm{mg} / \mathrm{kg}$ in Group C and Group D respectively produced drowsiness, walking in circle, drooping of the upper eyelids and droopy head in all the calves. Sleepy impression, lateral deviation of the head and relaxation of the muscle were also observed. Six calves out 
of 10 of Group C and Group D were found to have good sedation. Onset of sedation was $20.20 \pm 1.50 \mathrm{~min}$ in Group $\mathrm{C}$ and $21.40 \pm 1.29 \mathrm{~min}$ in Group D respectively.

\section{Effects of Various Sedative and Analgesic Drugs on Clinical Parameters}

Effects of various sedative and analgesic drugs on heart rates, respiration rates and rectal temperature in calf are presented in Table 01, Table 02 and Table 03..Before sedation, the mean values of heart rates, respiration rates and rectal temperature were $83.40 \pm 3.60$ per min, $28 \pm 1.30$ per min and $101.80 \pm 0.220 \mathrm{~F}$, respectively in Group A. These mean values of heart rates, respiration rates and rectal temperature 15 min after sedation were $73.40 \pm 2.66$ per min, $22 \pm 1.46$ per min and $101.60 \pm 0.21 \mathrm{oF}$ respectively. Heart rates and respiration rates were decreased significantly $(\mathrm{P}<0.01)$ after $15 \mathrm{~min}$ and also $30 \mathrm{~min}$ of sedation. But rectal temperature was not decreased significantly. Heart rates were significantly $(\mathrm{P}<0.01)$ decreased $45 \mathrm{~min}$ after sedation. Heart rates also decreased significantly $(\mathrm{P}<0.01)$ after $60 \mathrm{~min}$ of sedation as compared to pre sedative values.

In Group B, the mean values of heart rates, respiration rates and rectal temperature were $80.20 \pm 3.69$ per min, $25.80 \pm 1.93$ per $\min$ and $101.82 \pm 0.22^{\circ} \mathrm{F}$, respectively. These mean values $15 \mathrm{~min}$ after sedation were $71.20 \pm 3.68$ per $\min , 21.60 \pm 1.29$ per min and $101.58 \pm 0.21^{\circ} \mathrm{F}$, respectively. The heart rates and respiration rates were significantly $(\mathrm{P}<0.01)$ reduced after $15 \mathrm{~m}$ in and 30 min of sedation. Heart rates and respiration rates were significantly $(\mathrm{P}<0.01)$ decreased $45 \mathrm{~min}$ and $60 \mathrm{~min}$ of sedation as compared to pre sedative values. But rectal temperature was not decreased significantly.

In Group C, the mean values of heart rates, respiration rates and rectal temperature were $80 \pm 4.73$ per min, $80 \pm 4.73$ per min and $101.50 \pm 0.25^{\circ} \mathrm{F}$ respectively before sedation. During $15 \mathrm{~min}$ of sedation, heart rates, respiration rates and rectal temperature were $73.60 \pm 3.85$ per $\mathrm{min}$, $23.60 \pm 1.33$ per min and $101.40 \pm 0.25^{\circ} \mathrm{F}$ per min. respectively and they decreased significantly $(\mathrm{P}<0.01)$ as compared to presedative values. Heart rates and respiration rates were significantly $(\mathrm{P}<0.01)$ reduced during $15 \mathrm{~min}$ and 30 min after sedation. The respiration rate was not significantly $(\mathrm{P}>0.05)$ decreased 45 min and 60 min after sedation compared to pre-sedative values. But rectal temperature was not decreased significantly. The heart rates were significantly $(\mathrm{P}<0.05)$ increased and significantly $(\mathrm{P}<0.01) \quad$ decreased during $45 \mathrm{~min}$ and $60 \mathrm{~min}$ after sedation respectively.

In Group D, the mean values of heart rates, respiration rates, and rectal temperature were $74.40 \pm 2.32$ per min, $24.60 \pm 2.38$ per min and $101.70 \pm 0.20^{\circ} \mathrm{F}$ respectively before anaesthesia. Fifteen min after sedation heart rates and respiration rates were not significantly $(\mathrm{P}>0.05)$ decreased compared to pre-anaesthetic values. Heart rates and respiration rates were not significantly $(\mathrm{P}>0.05)$ decreased during $30 \mathrm{~min}$ and 45 min of sedation. The heart rates difference was not statistically significantly $(\mathrm{P}>0.05)$. Respiration rate was not significantly $(\mathrm{P}>0.05)$ increased. But rectal temperature was not decreased significantly.

\section{The Onset of Sedation}

The mean values of onset of sedation are presented in Table 04. In Group C, the onset of sedation occurred within 16-24 min and the mean value of onset was $20.2 \pm 3.35 \mathrm{~min}$. The mean value of onset was $21.4 \pm 2.88 \mathrm{~min}$ in Group D.

Onset of occurred within $18-25 \mathrm{~min}$ in all animals of Group D. There were statistically non significant $(\mathrm{P}>0.05)$ variations between different groups in term of onset of sedation. 
Table 01: Effects of sedative and analgesic agent on heart rate of calves

\begin{tabular}{|c|c|c|c|c|c|}
\hline Group & $\begin{array}{c}\text { Before } \\
\text { sedation }\end{array}$ & $\begin{array}{c}15 \text { minutes } \\
\text { after sedation }\end{array}$ & $\begin{array}{c}30 \text { minutes } \\
\text { after sedation }\end{array}$ & $\begin{array}{c}45 \text { minutes } \\
\text { after sedation }\end{array}$ & $\begin{array}{c}60 \text { minutes after } \\
\text { sedation }\end{array}$ \\
\hline A & $83.40 \pm 3.60$ & $73.40 \pm 2.66^{* *}$ & $68.40 \pm 2.42^{* *}$ & $67 \pm 2.77 * *$ & $67.80 \pm 3.07 * *$ \\
\hline B & $80.20 \pm 3.60$ & $71.20 \pm 3.68^{* *}$ & $66 \pm 2.85^{* *}$ & $61.20 \pm 2.48 * *$ & $60.20 \pm 3.22^{* *}$ \\
\hline D & $74.40 \pm 23$ & $71.40 \pm 0.60^{\mathrm{ns}}$ & $69.60 \pm 2.80^{\mathrm{ns}}$ & $67.60 \pm 3.59^{\mathrm{ns}}$ & $67.60 \pm 3.78^{\mathrm{ns}}$ \\
\hline
\end{tabular}

* Significant $(\mathrm{P}<0.05) * *$ Significant $(\mathrm{P}<0.01) \quad$ ns-nonsignificant $(\mathrm{P}>0.05)$

Table 02: Effects of sedative and analgeasic agent on respiration rate of calves

\begin{tabular}{|c|c|c|c|c|c|}
\hline Group & $\begin{array}{c}\text { Before } \\
\text { sedation }\end{array}$ & $\begin{array}{c}15 \text { minutes } \\
\text { after sedation }\end{array}$ & $\begin{array}{c}30 \text { minutes } \\
\text { after sedation }\end{array}$ & $\begin{array}{c}45 \text { minutes } \\
\text { after sedation }\end{array}$ & $\begin{array}{c}60 \text { minutes after } \\
\text { sedation }\end{array}$ \\
\hline A & $28 \pm 1.30$ & $22 \pm 1.46^{* *}$ & $20 \pm 1.67^{* *}$ & $19.40 \pm 1.54 * *$ & $20.40 \pm 1.12^{* *}$ \\
\hline B & $25.80 \pm 1.93$ & $21.60 \pm 1.29 * *$ & $18 \pm 1.05^{* *}$ & $16.60 \pm 0.93^{* *}$ & $16.80 \pm 1.53^{* *}$ \\
\hline C & $26.60 \pm 1.29$ & $23.60 \pm 1.33^{* *}$ & $24.80 \pm 2.27 * *$ & $22.60 \pm 2.01^{\text {ns }}$ & $23.80 \pm 1.69^{\text {ns }}$ \\
\hline D & $24.60 \pm 2.38$ & $21.80 \pm 2.08^{\mathrm{ns}}$ & $20.00 \pm 1.70^{\mathrm{ns}}$ & $18.20 \pm 2.20^{\mathrm{ns}}$ & $19.60 \pm 2.77^{\mathrm{ns}}$ \\
\hline
\end{tabular}

* Significant $(\mathrm{P}<0.05) * *$ Significant $(\mathrm{P}<0.01) \quad$ ns-nonsignificant $(\mathrm{P}>0.05)$

Table 03: Effects of sedative and analgeasic agent on rectal temperature $\left({ }^{0} \mathrm{~F}\right)$ of calves

\begin{tabular}{|c|c|c|c|c|c|}
\hline Group & $\begin{array}{c}\text { Before } \\
\text { sedation }\end{array}$ & $\begin{array}{c}15 \text { minutes } \\
\text { after sedation }\end{array}$ & $\begin{array}{c}30 \text { minutes } \\
\text { after sedation }\end{array}$ & $\begin{array}{c}45 \text { minutes } \\
\text { after sedation }\end{array}$ & $\begin{array}{c}60 \text { minutes after } \\
\text { sedation }\end{array}$ \\
\hline A & $101.80 \pm 0.22$ & $101.60 \pm 0.21$ & $101.26 \pm 0.20$ & $101.06 \pm 0.19$ & $100.96 \pm 0.14$ \\
\hline B & $101.82 \pm 0.22$ & $101.58 \pm 0.21$ & $101.36 \pm 0.21$ & $101.10 \pm 0.16$ & $100.90 \pm 0.15$ \\
\hline C & $101.50 \pm 0.25$ & $101.40 \pm 0.25$ & $101.14 \pm 0.21$ & $101.22 \pm 0.26$ & $100.70 \pm 0.15$ \\
\hline D & $101.70 \pm 0.20$ & $101.46 \pm 0.22$ & $101.28 \pm 0.22$ & $101.06 \pm 0.17$ & $100.90 \pm 0.17$ \\
\hline
\end{tabular}

Non-significant $(\mathrm{P}>0.05)$

\section{The Duration of Sedation}

The mean values of duration are presented in Table 04. There were statistically non significant $(\mathrm{P}>0.05)$ variations between different groups in term of duration of sedation.

\section{The Onset of Analgesia}

The mean values of onset of analgesia are presented in Table 05. The onset of analgesia occurred within 4-8 minutes in all animals of Group $\mathrm{A}$ and the mean values of onset was $5.60 \pm 1.52 \mathrm{~min}$. 
Table 04: Observation after using sedative in calf

\begin{tabular}{|c|c|c|c|c|c|c|}
\hline Group & $\begin{array}{l}\text { Initial dose rate } \\
/ \mathrm{kg} \mathrm{BW} \\
(\mathrm{mg})(\mathrm{MN} \pm \mathrm{SD})\end{array}$ & $\begin{array}{l}\text { Time of } \\
\text { onset of } \\
\text { sedation } \\
\text { in }(\mathrm{min}) \\
(\mathrm{MN} \pm \mathrm{SD})\end{array}$ & $\begin{array}{l}\text { Duration of } \\
\text { sedation in } \\
(\mathrm{min}) \\
(\mathrm{MN} \pm \mathrm{SD})\end{array}$ & $\begin{array}{l}\text { Further dose } \\
\text { rate } / \mathrm{kg} B W \\
(\mathrm{mg}) \\
(\mathrm{MN} \pm \mathrm{SD})\end{array}$ & $\begin{array}{l}\text { Extra } \\
\text { duration of } \\
\text { sedation } \\
\text { in(min) } \\
(\mathrm{MN} \pm \mathrm{SD})\end{array}$ & $\begin{array}{l}\text { Duration } \\
\text { of deep } \\
\text { sedation } \\
\text { in }(\mathrm{min}) \\
(\mathrm{MN} \pm \mathrm{SD})\end{array}$ \\
\hline $\mathrm{A}$ & $0.13 \pm 0.01$ & $8 \pm 1.58$ & $60.00 \pm 4.42$ & 0.00 & 0.00 & $22.6 \pm 5.32$ \\
\hline $\mathrm{B}$ & $0.12 \pm 0.01$ & $7 \pm 1.58$ & $60.00 \pm 20$ & 0.00 & 0.00 & $15.8 \pm 5.26$ \\
\hline $\mathrm{C}$ & $1.02 \pm 0.11$ & $20.2 \pm 3.35$ & $39.6 \pm 3.78$ & $0.44 \pm 0.11$ & $21.8 \pm 4.43$ & 0.00 \\
\hline $\mathrm{D}$ & $1.06 \pm 0.10$ & $21.4 \pm 2.88$ & $41.6 \pm 3.84$ & $0.44 \pm 0.11$ & $21 \pm 5.34$ & 0.00 \\
\hline $\begin{array}{c}\text { Level } \\
\text { of } \\
\text { sign. }\end{array}$ & $\mathrm{P}>0.05$ & $\mathrm{P}>0.05$ & $\mathrm{P}>0.05$ & $\mathrm{P}>0.05$ & $\mathrm{P}>0.05$ & $\mathrm{P}>0.05$ \\
\hline
\end{tabular}

In the onset of sedation occurred within 610 minutes in all animals of Group $\mathrm{A}$ and the mean values of onset was $8 \pm 1.58 \mathrm{~min}$. In Group B, the mean value of onset was $8.00 \pm 1.58 \mathrm{~min}$ and onset occurred within 6-10 $\mathrm{min}$.

In Group C, the onset of analgesia occurred within 2-5 min and the mean value of onset was $3 \pm 1.22 \mathrm{~min}$. The The mean value of onset was $7.8 \pm 1.30 \mathrm{~min}$.

In Group D. Onset of occurred within 6-9 min in all animals of Group D.There were statistically non-significantly $(\mathrm{P}>0.05)$ variations between different groups in term of onset of sedation.

\section{The Duration of Analgesia}

The mean values of duration of analgesia are presented in Table 05. There were statistically non-significantly $(\mathrm{P}>0.05)$ variations between different groups in term of duration of sedation. Xylazine hydrochloride produces rapid onset and a longer duration of sedation compared to diazepam and Xylazine hydrochloride significantly decreased respiration rates heart rates compared to diazepam. 2\% Lignocaine hydrochloride produces rapid onset of analgesia compared to $0.5 \%$ bupivacaine hydrochloride and $0.5 \%$ bupivacaine hydrochloride produces prolong duration of analgesia compared to $2 \%$ Lignocaine hydrochloride.

\section{Effects of Sedatives on Clinical Parameters}

The respiration rate significantly reduced with all the sedative agents.

These observations correspond with the findings of Lele and Bhokre (1985); Mohammad et al., 1996, Celly et al., 1997, Scholtysik et al., 1998 and Kumar et al., 1999). These reduction in respiration rate resulted from direct depression effect of sedative or premedicant on central nervous system (Peshin and Kumar, (1979) and Hasking et al., 1986).

Sedatives used in the present study influenced the activity of the cardoivascular system. The heart rate 
decreased significantly $(\mathrm{P}<0.01)$ with all the sedatives. After administration of xrylazine hydrochloride the heart rate were decreased significantly $(\mathrm{P}<0.01)$ in calves during 15, 30, 45 and 60 min. of sedation, reported in calves by other investigators (Dehghanti et al., 1991, Mohammad et al., 1996).

Xylazine produces bradicardia and hypotension due to central and peripheral suppression of sympathetic nervous system and as a result reduction of pulse rate occurs (Lacuata and Flores, 1972). In this study rectal temperature reduced but not significantly with all the sedatives.

The reduction of rectal temperature with xylazine hydrochloride and diazepam are agreeable with the earlier reports (chitale $e t$ al 1998). Reduction of rectal temperature with xylazine hydrochloride and diazepam might result from depression of thermoregulatory centre in the hypothalamus (Kumar et al., 1979). Kumar and singh (1977) suggested that reduction of body temperature is due to attribution of inhibitory effects of these agents on metabolism and heat dissipation.
The analgesic effects were as in different calf by using scoring method. There were insignificant differences in different variance after injection of same drug with same dose in different calf different amount of analgesic showed different effects i.e. peak time of analgesia and duration of analgesia were different. The findings were supported by Adetunji et al.,(2002). The physical characteristics like body weight, length of injection of the animal, amount of fat of the animals governed the distribution of injected drug in the injection side (Lee, 2006)

During analgesia, the peak time of analgesia was high with $0.5 \%$ bupivacaine hydrochloride amount the different local analgesic agents used in this experiment. This observation corresponds with the previous findings(De Rossi, 2005).The duration of analgesia with $0.5 \%$ bupivacaine hydrochloride was longer during analgesia than $2 \%$ lignocaine hydrochloride.

\section{Table 05: Effect of analgesic on herniorraphy in calf sedated with sedative and local infiltration form}

\begin{tabular}{|c|c|c|c|c|c|c|}
\hline Group & $\begin{array}{l}\text { Form of local } \\
\text { infiltration }\end{array}$ & $\begin{array}{l}\text { Initial } \\
\text { dose } \\
(\mathrm{ml})\end{array}$ & $\begin{array}{ll}\text { Time } & \text { of } \\
\text { onset } & \text { of } \\
\text { analgesia } & \text { in } \\
(\mathrm{min}) & \\
\end{array}$ & $\begin{array}{l}\text { Duration of } \\
\text { analgesia in } \\
(\mathrm{min})\end{array}$ & $\begin{array}{l}\text { Further } \\
\text { dose } \\
(\mathrm{ml})\end{array}$ & $\begin{array}{l}\text { Extra } \\
\text { duration } \\
\text { of } \\
\text { analgesi }\end{array}$ \\
\hline A & $\begin{array}{l}\text { Inverted "V" from } \\
\text { anterior side }\end{array}$ & 10.00 & $5.60 \pm 1.52$ & $39.60 \pm 5.77$ & $4.40 \pm 1.14$ & $\begin{array}{c}22.40 \pm 4 . \\
33\end{array}$ \\
\hline B & $\begin{array}{l}\text { Inverted "U" from } \\
\text { anterior side }\end{array}$ & 10.00 & $8.00 \pm 1.58$ & $55.8 \pm 1.58$ & $0.6 \pm 1.34$ & $\begin{array}{c}3.20 \pm 7.1 \\
5\end{array}$ \\
\hline $\mathrm{C}$ & Ring shape & 10.00 & $3 \pm 1.22$ & $43.6 \pm 5.81$ & $2.6 \pm 1.14$ & $\begin{array}{c}15.2 \pm 8.3 \\
5\end{array}$ \\
\hline $\mathrm{D}$ & $\begin{array}{l}\text { Inverted "L" from } \\
\text { both side }\end{array}$ & 10.00 & $7.8 \pm 1.30$ & $48 \pm 11.25$ & $2.4 \pm 1.94$ & $\begin{array}{c}14 \pm 10.3 \\
0\end{array}$ \\
\hline $\begin{array}{l}\text { Level of } \\
\text { sign. }\end{array}$ & $\mathrm{P}>0.05$ & $\mathrm{P}>0.05$ & $\mathrm{P}>0.05$ & $\mathrm{P}>0.05$ & $\mathrm{P}>0.05$ & $\mathrm{P}>0.05$ \\
\hline
\end{tabular}


N.C.Sarker, M.A.Hashim and B.P.Ray

This observation corresponds with the previous findings (Grubb et al., 1992). The protein binding characteristics of local analgesic agents influence the duration of action (Gissen et al., 1980). Lignocaine has intermediate duration of action. This observation was supported by Lemke and dawson (2000).

\section{Effect of Herniorraphy on Calves}

Out of 20 operated calves, only 2 developed stitch abscess and 3 cases reoccurred. The affected stitches were removed and dressed regularly. The reoccurred cases were again taken under operation. All these animals recovered with any further complication. During herniorraphy, most of the side effects were found in Group B and Group D were tympany, shivering, muscle tremor after using sedatives (xylazine $\mathrm{HCl}$ and diazepam ) and analgesic (Bupivacaine $\mathrm{HCl}$ ). In Group $\mathrm{C}$ muscle tremor was present after using sedative (Diazepam) and analgesic (Lignocaine $\mathrm{HCl}$ ). On the admission in the hospital the hernia affected calves were apparently bright and active had a good appetite, normal heat rate, respiration rate and rectal temperature. Similar observations have been reported elsewhere (Freeman et al., 1988).

\section{CONCLUSIONS}

Xylazine hydrochloride produces rapid onset and a longer duration of sedation and significantly decreased respiration rates and heart rates compared to diazepam. $2 \%$ Lignocaine hydrochloride produces rapid onset of analgesia compared to $0.5 \%$ bupivacaine hydrochloride. $0.5 \%$ bupivacaine hydrochloride produces prolong duration of analgesia compared to 2\% Lignocaine hydrochloride. Herniorraphy usually require longer time. According the time of sedation and analgesia should be longer. Thus, for herniorraphy a combination of xylazine hydrochloride and $0.5 \%$ bupivacaine hudrocloride is suggested for better performances of restraint. In few calves, however side effects e.g. shivering, tympany and muscle tremor have been observed.

\section{REFERENCES}

Anon. 1993. Economic review. Livestock Subsector, Directorate of livestock services, Bangladesh.

Adetunji A, Ajadi RA and Opia RE. 2002. A comparison of epidural anaesthesia with xylazine,bupivacaine and bupivacaine/ xylazine mixture in West African dwarf goats. Israel Journal of Veterinary Medicine 55(2): 70-75.

Carpenter et al., 2004. Evaluation of intraperitoneal and incisional lidocaine or bupipavacaine or analgesia following ovariohysterectomy in the dog. Veterinary Anaesthesia and Analgesia 31:46-52

Celly, McDonell WN, Young SS and Black WD. 1997. The comparative hypoxaemic effect Of four alpha2 adrnoceptor agonists ( Xylazine, romifidine, detomidine and medetomidine) in sheep. Journal of Veterinary Pharmacology and Therapeutics 20(6): 464-471.

Chitale DK, Amarpal ,Singh GR, Pawde AM and Gupta OP.1998.Alpha2 agonists with diazepam as preanaesthetics to ketamine anaesthesia in goats:Physiological and haematological study. Indian Journal of veterinary Surgery 19(2):103-104.

De Rossi R, Junqueira AL and Beretta MP. 2005. Analgesic and systemic effects of xylazine, lidocaine and their combination after subarachnoid administration in goats. Journal of African Veterinary Association 76(20: 79- South 84. 

Dehghani S, Behbodikhah A and Khorsand N. 1991. Clinical haematological and biochemical effects of xylazine, ketamine and their combination in cattle and sheep. Journal of Veterinary Anaesthesia pp.25-31.

Freeman, DE., Orsini, JA., Harison, IW., Muller, NS and Leitch, M. 1988. Complication of umbilical hernias in horses; 13 cases (1972-1980). Journal of American Veterinary Medical Association 190(6): 804-807.

Gissen A T, Covino GB and Gregvs J. 1980. Differential sensitivity of mammalian nerve fibres to anaesthetices agents. Anaesthesiology 53: 467-474.

Grubb TL, Riebold TW and Huber MJ. 1992. Comparison of Lignocaine and lignocaine/xylazine for caudal analgesia in horses. Journal of American Veterinary Medical Association 201:1187-1190.

Hall LW and Clarke KW. 1989. Veterinary Anaesthesia. 10 ${ }^{\text {th }}$ edn. Toronto, Ont.: Bailler Taindall, London. pp.75-364.

Hasking SC, Patz JD and Faver TB. 1986. Xylazine and xylazine-ketamine in dogs. Journal of American Veterinary Medical Association 47(3): 336-641.

Hasihm MA. 2004. The effect of local analgesics for postoperative pain control after overiohysterectomy in the dog and cat. A project report, Department of Clinical eterinary Science, University of Bristol, Langford House, Langford. Bristol BS 40 DU, Uk. pp. 1-8.

Hossain SS and Kumar A. 1988. Evaluatiion of lignocaine with and without amylalcohal as a long acting epidural analgesia in buffaloes. Indian Journal of Animal Science 58:103310.

Lele CM and Bhokre AP. 1985.Evaluation of xylazine as an anaesthetic agent in combination with certain anaesthetic drug in dogs. Indian Veterinary Journal 62(8):675-682.

Kumar A, Nigam JM and Sharma Sk. 1999. Diazepam in yaks. Indian Veterinary Journal 76:211-213.

Kumar A and Singh H. 1977. Chlorpromazine hydrochloride Triflupromazine hydrochloride and xylazine as tranquillizers in buffaloes. Indian Journal of Veterinary Surgery 54: 84-988.

Lacuata AQ and Flores FP.1972.A preliminary study on the anaesthetic value of Rompun in Dog. Philippine Journal of Veterinary Medicine 11(2):122-123.

Lee L. Local Analgesia and Anaesthesia. Center for Veterinary Health Science Oklahoma State University. Pp.25-30.

Leme KA and Dawson SD. 2000. Local and Regional Anaesthesia. Veterinary Clinic of North American Small Animal Practice 30(4):389-457.

Lumb WV and Jones EW. 1996. Veterinary Anaesthesia. $1^{\text {th }}$ edn. Lea and Febiger, Philadelphia. pp. 179-208.

Mohammad FK, Wahed RA and Al-Dabbagh BK. 1996. Stimulation of food intake by xylazine in. Journal of Veterinary Medicine 43(7):387-391.

Peacock EEJ and Van Winkle W. 1976. Wound repair: Surgery Gynecology and Obstetrics. 140:7-10.

Peshin PK and Kumar A. 1979. Physiologic and sedative effects of xylazine in buffaloes. Indian Veterinary Journal 56: 864-871.

Scholtysik-G, Regli F, Bruckmaier RM and Blum JW. 1998. The alpha2 adrenoceptor agonists xylazine and guafacine exert different central nervous system, but comparatable peripheral effects in calves. Journal of Veterinary Pharmacology and Therapeutics, 21(6): 477-484.

Slatter DH. 1985. Text Book of Small Animal Surgery. Philadelphia, WS Saunders Company, Vol. 1. pp. 351-373. 